\title{
The Relationship Between Hand Grip and Pinch Strengths and Disease Activity, Articular Damage, Pain, and Disability in Patients with Rheumatoid Arthritis
}

\author{
Romatoid Artritli Hastalarda Elle Kavrama ve Tutma Güçlerinin Hastalık Aktivitesi, \\ Eklem Hasarı, Ağrı ve Engellilik ile İlişkisi
}

Meryem DEDEOĞLU, Ümit GAFUROĞLU, Özlem YILMAZ, Hatice BODUR

Department of Physical Medicine and Rehabilitation, Ankara Numune Training and Research Hospital, Ankara, Turkey

\begin{abstract}
Objectives: This study aims to investigate the relationship of hand grip and pinch strengths with disease activity, functional impairment, functional disability, articular damage, pain, and disease duration in patients with rheumatoid arthritis (RA).
\end{abstract}

Patients and methods: Hand grip and pinch strength of 102 patients (78 females, 24 males; mean age $52.8 \pm 10.5$ years; range 26 to 69 years) with RA were assessed using a dynamometer. The Disease Activity Score 28 joints (DAS 28), the Duruoz Hand Index (DHI), the Signals of Functional Impairment (SOFI) index, the Health Assessment Questionnaire (HAQ), the Rheumatoid Arthritis Articular Damage (RAAD) score, the Modified Sharp Score (MSS) and the visual analog scale (VAS) were used to analyze the possible relationship.

Results: There was a statistically significant negative correlation between all grip and pinch strengths and the DAS 28 score, HAQ score, SOFI index, DHI, RAAD score, MSS, VAS, and disease duration $(p<0.001)$. The DHI, SOFI index, and $\mathrm{HAQ}$ parameters were the most strongly correlated variables with hand strengths. The DHI, SOFI index, RAAD score, DAS 28 score, HAQ score, and MSS showed a statistically significant positive correlation with each other $(p<0.001)$. The strongest correlation was between the HAQ and DHI $(r=0.876 ; p<0.001)$.

Conclusion: In this study, we found that hand grip and pinch strengths were negatively correlated with the disease activity, articular damage, pain, disease duration, functional impairment and disability in patients with RA. Our study results emphasize the importance of hand gripping and pinching abilities for the functional impairment and disability in patients with RA.

Key words: Grip; pinch; rheumatoid arthritis.
Amaç: Bu çalışmada romatoid artritli (RA) hastalarda elle kavrama ve tutma güçlerinin hastalık aktivitesi, fonksiyonel bozukluk ve engellilik, eklem hasarı, ağrı ve hastalık süresi ile olan ilişkisi incelendi.

Hastalar ve yöntemler: Yüz iki romatoid artritli hastanın (78 kadın, 24 erkek; ort. yaş $52.8 \pm 10.5$ yıl; dağılım 26-69 yıl) elle kavrama ve tutma güçleri dinamometre ile değerlendirildi. Muhtemel ilişkiyi değerlendirmek için 28 Eklemde Hastalık Aktivite Skoru (DAS 28), Duruöz El İndeksi (DHI), Fonksiyonel Bozukluk Sinyalleri (SOFI) indeksi, Sağlık Değerlendirme Ölçeği (HAQ), Romatoid Artrit Eklem Hasarı (RAAD) skoru, Modifiye Sharp Skoru (MSS) ve görsel analog ölçeği (GAÖ) kullanıldı.

Bulgular: Tüm kavrama ve tutma güçleri ile DAS 28 skoru, HAQ skoru, SOFI indeksi, DHI, RAAD skoru, MSS, GAÖ ve hastalık süresi arasında istatistiksel olarak anlamlı bir negatif ilişki bulundu $(p<0.001)$. El güçleri ile en güçlü ilişki gösteren parametreler $\mathrm{DHI}$, SOFI indeksi ve HAQ idi. Duruöz El İndeksi, SOFI indeksi, RAAD skoru, DAS 28 skoru, HAQ skoru ve MSS birbirleriyle anlamlı düzeyde pozitif ilişkili bulundu $(p<0.001)$. En güçlü ilişki $H A Q$ ile $D H I$ arasında idi $(r=0.876, p<0.001)$.

Sonuç: Bu çalışmada RA hastalarında elle kavrama ve tutma güçlerinin, hastalık aktivitesi, eklem hasarı, ağrı, hastalık süresi, fonksiyonel bozukluk ve engellilik ile negatif ilişkili olduğu bulundu. Çalışma bulgularımız, RA hastalarının elle kavrama ve tutma yetilerinin fonksiyonel bozukluk ve engellilik üzerindeki önemini vurgulamaktadır.

Anahtar sözcükler: Kavrama; tutma; romatoid artrit. 
Rheumatoid arthritis (RA) is a chronic, multisystemic, inflammatory disease with an unknown etiology that causes progressive destruction in the joints, ${ }^{[1]}$ with the hands and wrists being the most frequent actively involved joints. ${ }^{[2]}$ Hand involvement significantly affects daily living activities, ${ }^{[3]}$ and RA results in the deterioration of hand function by causing swelling, pain, and deformity. In addition, by causing a decrease in the range of motion in the joints as well as weakened muscles and loss of grip strength. ${ }^{[4]}$

The aims of our study were to evaluate the hand functions of patients with RA by using hand grip strengths and the Duruoz Hand Index (DHI) while also investigating the relationship between hand functions using the Disease Activity Score 28 (DAS 28), Signals of Functional Impairment (SOFI) index, Health Assessment Questionnaire (HAQ), Rheumatoid Arthritis Articular Damage (RAAD) score, modified Sharp Score (MSS), visual analog scale (VAS), and duration of disease. In addition, we investigated the correlation among the variables.

\section{PATIENTS AND METHODS}

The study was comprised of 102 patients (78 females, 24 males; mean age $52.8 \pm 10.5$ years; range 26 to 69 years) who were diagnosed with RA according to the American College of Rheumatology (ACR) classification criteria, ${ }^{[5]}$ and written informed consent was obtained from all of the participants. Patients with cervical disc disease, psychiatric disorders, or a previous cerebrovascular accident and those who had endocrinal [diabetes mellitus (DM), thyroid disease, etc.], traumatic, neurological, or muscular disorders that could affect hand functions were excluded. The patients were questioned to obtain their demographic information, and extraarticular involvement of RA involving the skin or eyes as well as problems involving the pulmonary, cardiac, neurological, hepatic, hematological, vascular, or renal systems was recorded. The joints of the patients were also examined, and the number of tender and swollen joints was noted. In addition, the rheumatoid factor (RF), erythrocyte sedimentation rate (ESR) and C-reactive protein (CRP) levels were ascertained.

Hand deformities that developed due to RA were also evaluated. Grip strength was measured using a Jamar ${ }^{\circledast}$ dynamometer or a Baseline ${ }^{\circledast}$ hydraulic hand dynamometer (Fabrication Enterprises, Inc., Irvington, NY, USA). ${ }^{[6]}$ Pinch strengths (tip-totip, lateral, and three-point pinch) were measured using a Baseline hydraulic pinch gauge (Fabrication
Enterprises, Irvington, NY, USA). Grip strength was measured while the patient was seated with the elbow flexed at a $90^{\circ}$ angle. The palm was turned inward toward the body, and the total inner hand surface grasped the dynamometer handle. Tip-to-tip pinch strength was measured with the palm facing down while force was exerted between the pads of the index finger and the thumb. Lateral pinch strength measurements were done with the palm facing medially while force was exerted between the pad of the thumb and the opposing lateral side of the middle phalanx of the index finger through the opposing surfaces. The remaining fingers were bent and held together to support the index finger. Three-point pinch strengths were measured with the palm facing down while force was exerted between the pads of the index and middle fingers together and the pad of the thumb. All measurements were performed three times on both hands,. First, the average of two hands was calculated followed by the average of three measurements. The values were recorded in kilograms. ${ }^{[7]}$

The functional disability of the hand was evaluated using the DHI. This index was developed in 1996 by Duruoz et al. ${ }^{[8]}$ and evaluates hand and wristrelated functions using 18 questions. The questions are answered using a scale between 0 and 5 , and the total score ranges between 0 and $90 .{ }^{[8]}$ French, English, and Turkish versions of the index have been produced, and the reliability and validity of the Turkish DHI have been proven in studies that were conducted on patients with stroke, traumatic hand flexor tendon injuries, and DM. ${ }^{[9-11]}$ The pain levels of the patients in our study were determined using a $0-100 \mathrm{~mm}$ VAS pain intensity scale. ${ }^{[12]}$ Disease activity was determined with the DAS 28 and calculated using a formula which took into account the number of swollen and tender joints, ESR, and the patients' assessments of global disease activity. ${ }^{[13]}$ The level of disability was investigated using the HAQ, which consists of 20 questions in eight subcategories: dressing and grooming, arising, eating, walking, hygiene, reach, grip, and common daily activities. In this questionnaire, the patients receive a score of 0 if they have no difficulty at all, 1 if they have some difficulty, 2 if they have much difficulty or need the use of an assistive device, and 3 if they are unable to do the activity. In this study, the highest score obtained for any question in a given sub-category determined the score for that sub-category, and the total HAQ score was calculated using the mean of the sub-categories. The Turkish version of the HAQ was shown to be reliable and valid by Küçükdeveci, et al. ${ }^{[14]}$ 
Functional impairment of our study participants was evaluated using the SOFI index, a performance test that has three parts and evaluates hand along with upper and lower extremity functions. A total score of between 0 and 44 is possible, with the highest score indicating the worst function. ${ }^{[15]}$ No validation study of the Turkish version has been conducted yet. The RAAD index is used to clinically evaluate articular damage and is based on an examination of 35 large and small joints. In this study, the scoring was done as follows: $0=$ no articular damage; $1=$ partially damaged; and $2=$ severe damage, ankylosis, or prosthesis. The result was then recorded, with a possible maximum score of 70 . The original form was proven to be a reliable and valid tool, ${ }^{[16]}$ but the validity of the Turkish version has not yet been verified.

The MSS was used in our study to evaluate structural articular damage via plain X-rays taken of both hands. Furthermore, it can also be uses to detect joint erosion and joint space narrowing. The erosion score per each joint of the hands ranges from 0 to 5 , and joint space narrowing and joint subluxation or luxation are combined in a single score that ranges from 0 to 4 . The maximum total erosion score for two hands is 160 , the highest narrowing score is 120 , and the maximum MSS score is $280 .^{[17]}$

\section{Statistical analysis}

The Kolmogrov-Smirnov and Shapiro-Wilk tests were used to test normality while non-parametric tests were preferred for testing the results and scales,. The differences in proportions between the groups were compared using a chi-square or Fisher's exact test where appropriate. Continuous variables, including age, disease duration, and morning stiffness (MS) duration, were compared using the Mann-Whitney $U$ test among categories of grouped variables, and the degree of correlation between the variables was calculated using Spearman's rho correlation coefficients. General descriptive statistics were summarized using numbers and percentages for categorical variables and median (min-max)

\begin{tabular}{|c|c|c|c|c|c|}
\hline Variables & $\mathrm{n}$ & $\%$ & Mean \pm SD & Median & Min.-max. \\
\hline \multicolumn{6}{|l|}{ Gender } \\
\hline Female & 78 & 76.5 & & & \\
\hline Male & 24 & 23.5 & & & \\
\hline Age (years) & & & $52.83 \pm 10.50$ & 53.00 & $26-69$ \\
\hline Disease duration (years) & & & $13.55 \pm 9.03$ & 12.00 & $1-37$ \\
\hline Morning stiffness duration (minutes) & & & $57.96 \pm 95.26$ & 10.00 & $0-420$ \\
\hline Number of tender joints $(0-28)$ & & & $7.59 \pm 11.76$ & 1.50 & $0-28$ \\
\hline Number of swollen joints $(0-28)$ & & & $0.80 \pm 2.09$ & 0.0 & $0-12$ \\
\hline C-reactive protein $(\mathrm{mg} / \mathrm{L})$ & & & $1.40 \pm 1.54$ & 0.80 & $0.5-9.3$ \\
\hline Erythrocyte sedimentation rate ( $\mathrm{mm} /$ hour) & & & $29.62 \pm 15.47$ & 27.00 & $7-75$ \\
\hline Rheumatoid factor positivity & & 63.7 & & & \\
\hline \multicolumn{6}{|l|}{ Dominant hand } \\
\hline Right & & 95.1 & & & \\
\hline Left & & 4.9 & & & \\
\hline \multicolumn{6}{|l|}{ Hand surgery } \\
\hline Positive & & 10.8 & & & \\
\hline Negative & & 89.2 & & & \\
\hline \multicolumn{6}{|l|}{ Extraarticular involvement } \\
\hline Positive & & 33.3 & & & \\
\hline Negative & & 66.7 & & & \\
\hline \multicolumn{6}{|l|}{ Working } \\
\hline Yes & & 24.5 & & & \\
\hline No & & 75.5 & & & \\
\hline \multicolumn{6}{|l|}{ Marital status } \\
\hline Married & & 82.4 & & & \\
\hline Single & & 2.9 & & & \\
\hline Widow & & 14.7 & & & \\
\hline Education (years) & 4.33 & & & 5.00 & $0-15$ \\
\hline
\end{tabular}




\begin{tabular}{lccc}
\hline Table 2. Hand deformities of the patients & & \\
\hline Deformities & $\mathrm{n}$ & $\%$ \\
\hline At least one hand deformity & 95 & 93 \\
Synovial hypertrophy & 68 & 66.7 \\
Metacarpophalangeal joint subluxation & 26 & 25.5 \\
Ulnar deviation of MCP joints & 89 & 87.3 \\
Radial deviation of the wrists & 37 & 36.3 \\
Boutonniere deformity & 43 & 42.2 \\
Swan neck deformity & 34 & 33.3 \\
Fusiform finger & 37 & 36.3 \\
Z deformity of the thumb & 64 & 62.7 \\
Caput ulna syndrome & 18 & 17.6 \\
Other deformities & 15 & 14.7 \\
\hline MCP: Metacarpophalangeal. & & \\
\hline
\end{tabular}

while mean \pm standard deviation (SD) was utilized for continuous variables. Statistical analyses were performed with the SPSS version 15.0 for Windows software program (SPSS, Inc., Chicago, IL, USA), and a $\mathrm{p}$ value of less than 0.05 was considered to be statistically significant.

\section{RESULTS}

The demographic characteristics of the patients are shown in Table 1. The mean disease duration was $13.6 \pm 9$ years. Furthermore, the RF was positive in $63.7 \%$ of the patients, and the right hand was dominant in $95.1 \%$. The deformities and their proportions are presented in Table 2, and at least one hand deformity was found in $93 \%$ of the patients.

The clinical parameters of the patients are shown in Table 3. The mean values for the clinical parameters were as follows: grip strength $21.2 \pm 9.8 \mathrm{~kg}$, lateral pinch strength $5.9 \pm 2.2 \mathrm{~kg}$, tip-to-tip pinch strength $3.9 \pm 1.7 \mathrm{~kg}$, three-point pinch strength $5 \pm 2 \mathrm{~kg}$,
DAS 28 3.8 \pm 1.4 , HAQ $0.9 \pm 0.8$, SOFI index 16.2 \pm 8.4 , DHI 16.5 \pm 19.4 , RAAD score $12.1 \pm 8.2$, MSS $45.3 \pm 25.7$, and VAS $4.5 \pm 2.9$.

The correlations between the variables were investigated in the second stage of the study, and the relationship between grip and pinch strengths and the other variables is shown in Table 4. There were statistically significant negative correlations between all grip and pinch strengths and the DAS 28, HAQ, SOFI index, DHI, RAAD scores, MSS, VAS, and disease duration $(\mathrm{p}<0.001)$, with the DHI, SOFI index, and HAQ having the highest associations, followed by the DAS 28 and VAS. Grip and pinch strengths and age were not significantly correlated ( $\mathrm{p}>0.05)$. Additionally, the grip and pinch strengths with respect to gender are shown in Table 5 , and these were significantly greater in the males than the females.

Comparisons between the disease evaluation tools, except for grip and pinch strengths, are shown in Table 6 . There were statistically significant positive correlations between the SOFI index and the DAS 28, HAQ, DHI, RAAD scores, MSS, VAS, and disease duration $(p<0.001)$. There were also statistically significant positive correlations between the DHI and the DAS 28, HAQ, RAAD scores, MSS, VAS, and disease duration $(\mathrm{p}<0.001)$, and the RAAD scores were significantly related to the DAS 28 , HAQ, DHI, MSS, VAS, and disease duration $(\mathrm{p}<0.001)$. Furthermore, statistically significant positive correlations existed between the DAS 28 and the HAQ, MSS, and VAS $(\mathrm{p}<0.001)$. A statistically non-significant weak positive correlation was also found between the DAS 28 and disease duration ( $p>0.05$ ), wheras there were statistically significant positive correlations between the HAQ and the VAS, MSS, and disease duration $(\mathrm{p}<0.001)$. Although there was a statistically significant positive correlation

\begin{tabular}{lccc} 
Table 3. Clinical characteristic of the patients $(\mathrm{n}=102)$ & & \\
\hline & Mean \pm SD & Median & Min.-max. \\
\hline Grip strength (kg) & $21.2 \pm 9.8$ & 19 & $6.3-54$ \\
Lateral pinch strength (kg) & $5.9 \pm 2.2$ & 5.9 & $1.5-13.5$ \\
Tip-to-tip pinch strength (kg) & $3.9 \pm 1.7$ & 3.5 & $0.9-8.5$ \\
Three-point pinch strength (kg) & $5 \pm 2$ & 4.9 & $0.5-8.8$ \\
Disease Activity Score 28 & $3.8 \pm 1.4$ & 3.3 & $1.6-7.1$ \\
Health Assessment Questionnaire (0-3) & $0.9 \pm 0.8$ & 0.8 & $0-2.9$ \\
Signals of Functional Impairment Index (0-44) & $16.2 \pm 8.4$ & 14.5 & $0-38$ \\
Duruoz Hand Index (0-90) & $16.5 \pm 19.4$ & 7.5 & $0-77$ \\
Rheumatoid Arthritis Articular Damage scores (0-70) & $12.1 \pm 8.2$ & 11 & $0-38$ \\
Modified Sharp score (0-280) & $45.3 \pm 25.7$ & 38 & $8-114$ \\
Visual analog scale (0-10 cm) & $4.5 \pm 2.9$ & 5 & $0-10$ \\
SD: Standard deviation; Min.: Minimum; Max.: Maximum. & & &
\end{tabular}


Table 4. Correlation coefficients (r) between grip and pinch strengths and other variables

\begin{tabular}{|c|c|c|c|c|}
\hline & Grip & Lateral pinch & Tip-to-tip pinch & Three-point pinch \\
\hline \multicolumn{5}{|c|}{ Disease Activity Score 28} \\
\hline $\mathrm{r}$ & $-0.493^{\star *}$ & $-0.474^{* *}$ & $-0.492^{\star *}$ & $-0.526^{* *}$ \\
\hline $\mathrm{p}$ value & 0.000 & 0.000 & 0.000 & 0.000 \\
\hline \multicolumn{5}{|c|}{ Health Assessment Questionnaire } \\
\hline $\mathrm{r}$ & $-0.635^{\star *}$ & $-0.598^{\star *}$ & $-0.521^{\star *}$ & $-0.622^{\star *}$ \\
\hline $\mathrm{p}$ value & 0.000 & 0.000 & 0.000 & 0.000 \\
\hline \multicolumn{5}{|c|}{ Signs of Functional Impairment Index } \\
\hline $\mathrm{r}$ & $-0.643^{\star *}$ & $-0.562^{\star \star}$ & $-0.439^{\star \star}$ & $-0.583^{\star \star}$ \\
\hline $\mathrm{p}$ value & 0.000 & 0.000 & 0.000 & 0.000 \\
\hline \multicolumn{5}{|c|}{ Duruoz Hand Index } \\
\hline $\mathrm{r}$ & $-0.687^{\star *}$ & $-0.640^{* *}$ & $-0.553^{\star *}$ & $-0.653^{\star *}$ \\
\hline $\mathrm{p}$ value & 0.000 & 0.000 & 0.000 & 0.000 \\
\hline \multicolumn{5}{|c|}{ Rheumatoid Arthritis Articular Damage scores } \\
\hline $\mathrm{r}$ & $-0.462^{\star *}$ & $-0.445^{\star *}$ & $-0.316^{*}$ & $-0.435^{\star *}$ \\
\hline $\mathrm{p}$ value & 0.000 & 0.000 & 0.001 & 0.000 \\
\hline \multicolumn{5}{|c|}{ Modified Sharp score } \\
\hline $\mathrm{r}$ & $-0.462^{\star *}$ & $-0.442^{\star \star}$ & $-0.333^{\star}$ & $-0.429^{\star *}$ \\
\hline $\mathrm{p}$ value & 0.000 & 0.000 & 0.001 & 0.000 \\
\hline \multicolumn{5}{|c|}{ Visual analog scale } \\
\hline $\mathrm{r}$ & $-0.493^{\star *}$ & $-0.426^{\star *}$ & $-0.387^{\star *}$ & $-0.472^{\star *}$ \\
\hline $\mathrm{p}$ value & 0.000 & 0.000 & 0.000 & 0.000 \\
\hline \multicolumn{5}{|c|}{ Disease duration } \\
\hline $\mathrm{r}$ & $-0.419^{\star \star}$ & $-0.449^{\star *}$ & $-0.336^{*}$ & $-0.454^{\star \star}$ \\
\hline $\mathrm{p}$ value & 0.000 & 0.000 & 0.001 & 0.000 \\
\hline \multicolumn{5}{|l|}{ Age } \\
\hline $\mathrm{r}$ & -0.112 & -0.091 & -0.034 & -0.114 \\
\hline $\mathrm{p}$ value & 0.262 & 0.364 & 0.734 & 0.253 \\
\hline
\end{tabular}

between the MSS and disease duration $(\mathrm{p}<0.001)$, no relationship was found between those scores and VAS ( $>0.05)$. Furthermore, there was not a statistically significant correlation between the VAS and disease duration $(\mathrm{p}>0.05)$. The strongest correlation among the variables was between the HAQ and DHI.
Neither the grip and pinch strengths, the DAS 28, HAQ, SOFI index, DHI, RAAD scores, nor mean VAS showed any statistically significant differences when the seropositive and seronegative patients were compared ( $p>0.05)$. However, the MSS was higher in the RF positive cases $(p=0.002)$. The median MSS values of

\begin{tabular}{|c|c|c|c|c|c|}
\hline & $\mathrm{n}$ & Mean \pm SD & Median & Min.-max. & $p$ \\
\hline \multicolumn{6}{|c|}{ Grip strength } \\
\hline Female & 78 & $18.1^{\star} \pm 7.1$ & $16.8^{\star}$ & $6.3-34$ & \multirow{2}{*}{0.000} \\
\hline Male & 24 & $31.1^{\star} \pm 11.1$ & $30^{*}$ & $13.3-54$ & \\
\hline \multicolumn{6}{|c|}{ Lateral pinch strength } \\
\hline Female & 78 & $5.2^{\star} \pm 1.8$ & $5.2^{*}$ & $1.6-8.6$ & \multirow[b]{2}{*}{0.000} \\
\hline Male & 24 & $8.1^{*} \pm 2.1$ & $8.6^{\star}$ & $3.4-13.5$ & \\
\hline \multicolumn{6}{|c|}{ Tip-to-tip pinch strength } \\
\hline Female & 78 & $3.4^{\star} \pm 1.4$ & $3^{*}$ & $0.9-7.5$ & \multirow{2}{*}{0.000} \\
\hline Male & 24 & $5.4^{\star} \pm 1.5$ & $5.5^{*}$ & $1.8-8.5$ & \\
\hline \multicolumn{6}{|c|}{ Three-point pinch strength } \\
\hline Female & 78 & $4.3^{\star} \pm 1.6$ & & & \multirow{2}{*}{0.000} \\
\hline Male & 24 & $7^{\star} \pm 1.5$ & & & \\
\hline
\end{tabular}




\begin{tabular}{|c|c|c|c|c|c|c|c|}
\hline & DHI & SOFI & RAAD & DAS28 & HAQ & MSS & VAS-pain \\
\hline \multicolumn{8}{|c|}{ Duruöz Hand Index } \\
\hline $\mathrm{r}$ & & $0.576^{\star *}$ & $0.438^{\star *}$ & $0.615^{\star *}$ & $0.876^{* *}$ & $0.370^{* *}$ & $0.658^{\star *}$ \\
\hline $\mathrm{p}$ value & & 0.000 & 0.000 & 0.000 & 0.000 & 0.000 & 0.000 \\
\hline \multicolumn{8}{|c|}{ Signals of functional impairment index } \\
\hline $\mathrm{r}$ & $0.576^{* *}$ & & $0.605^{\star *}$ & $0.435^{\star *}$ & $0.599^{\star *}$ & $0.537^{\star *}$ & $0.464^{* *}$ \\
\hline $\mathrm{p}$ value & 0.000 & & 0.000 & 0.000 & 0.000 & 0.000 & 0.000 \\
\hline \multicolumn{8}{|c|}{ Rheumatoid arthritis articular damage scores } \\
\hline $\mathrm{r}$ & $0.438^{\star *}$ & $0.605^{\star *}$ & & $0.271^{\star}$ & $0.362^{* *}$ & $0.408^{* *}$ & $0.215^{\star}$ \\
\hline $\mathrm{p}$ value & 0.000 & 0.000 & & 0.006 & 0.000 & 0.000 & 0.030 \\
\hline \multicolumn{8}{|c|}{ Disease activity score 28} \\
\hline $\mathrm{r}$ & $0.615^{\star *}$ & $0.435^{\star *}$ & $0.271^{*}$ & & $0.657^{\star *}$ & $0.225^{\star}$ & $0.671^{* *}$ \\
\hline $\mathrm{p}$ value & 0.000 & 0.000 & 0.006 & & 0.000 & 0.023 & 0.000 \\
\hline \multicolumn{8}{|c|}{ Health assessment questionnaire } \\
\hline $\mathrm{r}$ & $0.876^{\star *}$ & $0.599^{\star *}$ & $0.362^{\star *}$ & $0.657^{\star *}$ & & $0.345^{\star *}$ & $0.682^{* *}$ \\
\hline $\mathrm{p}$ value & 0.000 & 0.000 & 0.000 & 0.000 & & 0.000 & 0.000 \\
\hline \multicolumn{8}{|c|}{ Modified Sharp score } \\
\hline $\mathrm{r}$ & $0.370^{\star *}$ & $0.537^{\star *}$ & $0.408^{\star *}$ & $0.225^{\star}$ & $0.345^{\star *}$ & & 0.129 \\
\hline $\mathrm{p}$ value & 0.000 & 0.000 & 0.000 & 0.023 & 0.000 & & 0.197 \\
\hline \multicolumn{8}{|c|}{ Visual analog scale } \\
\hline $\mathrm{r}$ & $0.658^{\star \star}$ & $0.464^{\star \star}$ & $0.215^{\star}$ & $0.671^{\star *}$ & $0.682^{* *}$ & 0.129 & \\
\hline $\mathrm{p}$ value & 0.000 & 0.000 & 0.030 & 0.000 & 0.000 & 0.197 & \\
\hline \multicolumn{8}{|c|}{ Disease duration } \\
\hline $\mathrm{r}$ & $0.380^{\star *}$ & $0.500^{\star *}$ & $0.493^{*}$ & 0.147 & $0.312^{*}$ & $0.561^{\star *}$ & 0.148 \\
\hline $\mathrm{p}$ value & 0.000 & 0.000 & 0.000 & 0.140 & 0.001 & 0.000 & 0.139 \\
\hline
\end{tabular}

RF (+) and RF (-) patients were 45 (range, 9-114) and 31 (range, 8-98), respectively.

\section{DISCUSSION}

We found negative correlations between grip and pinch strengths and the DAS 28, HAQ, SOFI index, DHI, RAAD scores, MSS, VAS, and disease duration in this study, with the strongest being between the DHI, SOFI index, and HAQ. The HAQ is frequently used for determining a rational course of therapy for diseases and for evaluating treatment efficacy. It is often thought to be as important as laboratory and clinical investigations for patient follow-up. In our study, the DHI was the most strongly correlated variable with grip and pinch strengths. Determination of a significant positive correlation between the dynamometric measurements and the DHI was crucial since it is a scale in which the patients reflect their opinions concerning their hand function. Our results emphasized the importance of grasping and pinching skills on the functionality of the hand. In 2005, Bodur et al. ${ }^{[18]}$ reported that hand disability was related to grip and pinch strength measurements. In their study, hand disability was evaluated using questions from the HAQ that focused on hand functions. Similarly, Nampei et al. ${ }^{[19]}$ found that pinch strength was related to hand disability and deformities of the thumb and index finger. In contrast to those two studies, we evaluated hand disability using the DHI, an index that was developed specifically to assess hand disability in RA patients. In addition to hand disability, we also investigated the relationship between grip strength and general disability, using the HAQ, and impairment, using the SOFI index. Similar to our study, Taştekin et al. ${ }^{[20]}$ reported that grip and pinch strengths (tip-to-tip pinch, key (lateral) pinch, and three-point pinch) were negatively correlated with the DAS 28, DHI, and HAQ. Different from our study they determined that the hand strengths were more strongly correlated with the DAS 28 than the DHI. In the Taştekin et al. ${ }^{[20]}$ study, the mean disease duration was shorter than in our study (10.1 vs. 13.55 years, respectively) and the hand deformity ratios were lower than in our study. Furthermore, they reported that metacarpophalangeal subluxation, swan neck, and boutonniere deformities did not affect grip and pinch strengths, but they found that ulnar deviation deformities were negatively correlated with these strengths. There was approximately twice the 
number of ulnar deviations in when our patients compare with theirs ( $87 \%$ versus $43 \%$ ), but this could have been the result of longer disease durations and the higher percentage of hand deformities in our study. In patients with late RA, grip and pinch strengths seem to be affected more by the patients' functional status, whereas in patients with relatively early RA and relatively lesser deformities, hand strength is affected more by disease activity. A limitation of our study was that we did not investigate the relationship between grip and pinch strengths and hand deformities.

Nampei et al. ${ }^{[19]}$ evaluated the hands of 42 RA patients. In contrast to our study, they used a hand disability index to determine functional status, and they found that all pinch strengths were correlated with that index. They also analyzed the relationship between finger deformities and pinch strengths and reported that pinch strengths were weaker with mutilated deformities of the thumb and metacarpophalangeal volar dislocation of the index finger.

Males and females show some differences regarding the progression and results of RA. Similar to the healthy population, the mean grip and pinch strengths of males with RA are greater than that of females. ${ }^{[2]} \mathrm{In}$ addition, data in the current literature has also shown more grip strength in male versus female patients.

When we evaluated the relationship between the DHI and other variables other than hand strength, we observed that the DHI had a stronger correlation with the HAQ. This finding emphasized the effect of hand disability on patients' global disability.

A number of radiological scoring methods have been developed to investigate radiological alterations in RA, and we chose the most frequently used method, the MSS, which was modified by van der Heijde, ${ }^{[17]}$ in our study, disease duration was longer and disease activity was higher in patients with more severe articular damage. The positive correlations between the MSS and grip and pinch strengths, the HAQ, SOFI, and DHI showed that impairment and disability increase in conjunction with radiological damage. Kuper ${ }^{[22]}$ and van der Heijde ${ }^{[23]}$ also reported that radiological damage was related to the HAQ.

A disadvantage of radiographs is their inability to give information related to soft tissues. ${ }^{[2]}$ A clinical evaluation of articular damage is vital for detecting disease progression and for providing long-term results. The RAAD, developed by Zijlstra et al., ${ }^{[16]}$ is a fast and easy-to-use method that assesses articular damage via a physical examination. A study by Bodur et al. ${ }^{[18]}$ compared the hand-related questions of the HAQ with RAAD scores and found a significant positive correlation. In our study, there was a negative correlation between the RAAD scores and grip and pinch strengths; however, positive correlations were noted between the RAAD scores and disease duration and disease activity as well as the VAS, HAQ, DHI, SOFI index, and MSS. These results illustrate the connection between the progression of articular damage and the increase in functional impairment. Although we found no correlation between seropositivity, an indicator of poor prognosis, and grip and pinch strengths along with the DAS 28, VAS, RAAD scores, HAQ, SOFI index, and DHI, the presence of higher MSS values in seropositive patients advances the role of seropositivity in the radiological progression.

Pain is the most common complaint of RA patients. ${ }^{[25]}$ The Outcome Measures in Clinical Trials (OMERACT) has suggested that this is the main variable in the central outcome measures set. ${ }^{[26]}$ Pain is more common in women than men. ${ }^{[27]}$ Several studies have reported that even when adjusted for disease severity and physical function, females with RA suffer more pain, ${ }^{[28]}$ and their HAQ scores are higher. ${ }^{[29]}$ Björk et al. $^{[30]}$ reported that as the severity of pain increased, the level of hand disability also increased while activities of daily living (ADL) deteriorated. Similar to the current literature, we found positive correlations between the VAS and the DHI, SOFI index, HAQ, RAAD scores, and DAS 28 in our study.

In conclusion, we determined that grip and pinch strengths were significantly related to disability and impairment, disease activity, articular damage, pain, and disease duration in the RA patients in our study. These results emphasize the importance that grasping and pinching skills have on hand disability and functional impairment. We believe that by keeping disease activity under control, preventing articular damage, and protecting and rehabilitating the hand, disability in RA patients can lessened or possibly even eliminated.

\section{Declaration of conflicting interests}

The authors declared no conflicts of interest with respect to the authorship and/or publication of this article.

\section{Funding}

The authors received no financial support for the research and/or authorship of this article. 


\section{REFERENCES}

1. Harris ED, Budd RC, Firestein GS, Ruddy S, Harris E. Clinical features of rheumatoid arthritis. In: Haris editor. Kelley's textbook of rheumatology. 7th ed. Philadelphia: W.B. Saunders; 2004. p. 1043-78.

2. O'Brien AV, Jones P, Mullis R, Mulherin D, Dziedzic K. Conservative hand therapy treatments in rheumatoid arthritis--a randomized controlled trial. Rheumatology (Oxford) 2006;45:577-83.

3. Towheed TE, Anastassiades TP. Rheumatoid hand. Practical approach to assessment and management. Can Fam Physician 1994;40:1303-9.

4. Fraser A, Vallow J, Preston A, Cooper RG. Predicting 'normal' grip strength for rheumatoid arthritis patients. Rheumatology (Oxford) 1999;38:521-8.

5. Arnett FC, Edworthy SM, Bloch DA, McShane DJ, Fries JF, Cooper NS, et al. The American Rheumatism Association 1987 revised criteria for the classification of rheumatoid arthritis. Arthritis Rheum 1988;31:315-24.

6. Fess EE. Documentation: essential elements of an upper extremity assesment battery. In: Hunter JM, Mackin EL, Callahan AD, Skirven TM, Schneider LH, Osterman AL, editors. Rehabilitation of the hand and upper extremity. 5th ed. Saint Louis: Mosby; 2002. p. 63-84.

7. Mathiowetz V, Weber K, Volland G, Kashman N. Reliability and validity of grip and pinch strength evaluations. J Hand Surg Am 1984;9:222-6.

8. Duruöz MT, Poiraudeau S, Fermanian J, Menkes CJ, Amor B, Dougados M, et al. Development and validation of a rheumatoid hand functional disability scale that assesses functional handicap. J Rheumatol 1996;23:1167-72.

9. Sezer N, Yavuzer G, Sivrioglu K, Basaran P, Koseoglu BF. Clinimetric properties of the Duruoz hand index in patients with stroke. Arch Phys Med Rehabil 2007;88:309-14.

10. Erçalik T, Şahin F, Erçalik C, Doğu B, Dalgiç S, Kuran B. Psychometric characteristics of Duruoz Hand Index in patients with traumatic hand flexor tendon injuries. Disabil Rehabil 2011;33:1521-7. doi: 10.3109/09638288.2010.533244.

11. Turan Y, Duruöz MT, Aksakalli E, Gürgan A. Validation of Duruöz Hand Index for diabetic hand dysfunction. J Investig Med 2009;57:887-91. doi: 10.231/ JIM.0b013e3181b91c82.

12. Carlsson AM. Assessment of chronic pain. I. Aspects of the reliability and validity of the visual analogue scale. Pain 1983;16:87-101.

13. Balsa A, Carmona L, González-Alvaro I, Belmonte MA, Tena X, Sanmartí R, et al. Value of Disease Activity Score 28 (DAS28) and DAS28-3 compared to American College of Rheumatology-defined remission in rheumatoid arthritis. J Rheumatol 2004;31:40-6.

14. Küçükdeveci AA, Sahin H, Ataman S, Griffiths B, Tennant A. Issues in cross-cultural validity: example from the adaptation, reliability, and validity testing of a Turkish version of the Stanford Health Assessment Questionnaire. Arthritis Rheum 2004;51:14-9.
15. Eberhardt KB, Svensson B, Mortiz U. Functional assessment of early rheumatoid arthritis. Br J Rheumatol 1988;27:364-71.

16. Zijlstra TR, Bernelot Moens HJ, Bukhari MA. The rheumatoid arthritis articular damage score: first steps in developing a clinical index of long term damage in RA. Ann Rheum Dis 2002;61:20-3.

17. van der Heijde D. How to read radiographs according to the Sharp/van der Heijde method. J Rheumatol 1999;26:743-5.

18. Bodur H, Yilmaz O, Keskin D. Hand disability and related variables in patients with rheumatoid arthritis. Rheumatol Int 2006;26:541-4.

19. Nampei A, Shi K, Hirao M, Murase T, Yoshikawa H, Hashimoto J. Association of pinch strength with hand dysfunction, finger deformities and contact points in patients with rheumatoid arthritis. Clin Exp Rheumatol 2011;29:1061.

20. Tastekin N, Uzunca K, Birtane M, Kabayel DD, Ozturk G. The relationship of range of motion and grip strength of the hand with disease activity, hand functions and disability in patients with rheumatoid arthritis. Rheumatism 2006;21:13-7.

21. Thyberg I, Hass UA, Nordenskiöld U, Skogh T. Survey of the use and effect of assistive devices in patients with early rheumatoid arthritis: a two-year followup of women and men. Arthritis Rheum 2004;51:413-21.

22. Kuper $H H$, van Leeuwen MA, van Riel PL, Prevoo ML, Houtman PM, Lolkema WF, et al. Radiographic damage in large joints in early rheumatoid arthritis: relationship with radiographic damage in hands and feet, disease activity, and physical disability. Br J Rheumatol 1997;36:855-60.

23. van der Heijde D, Landewé $R$, van Vollenhoven $R$, Fatenejad S, Klareskog L. Level of radiographic damage and radiographic progression are determinants of physical function: a longitudinal analysis of the TEMPO trial. Ann Rheum Dis 2008;67:1267-70. doi: 10.1136/ ard.2007.081331.

24. Magni-Manzoni S, Rossi F, Pistorio A, Temporini F, Viola S, Beluffi G, et al. Prognostic factors for radiographic progression, radiographic damage, and disability in juvenile idiopathic arthritis. Arthritis Rheum 2003;48:3509-17.

25. Heiberg T, Finset A, Uhlig T, Kvien TK. Seven year changes in health status and priorities for improvement of health in patients with rheumatoid arthritis. Ann Rheum Dis 2005;64:191-5.

26. Felson DT, Anderson JJ, Boers M, Bombardier C, Chernoff M, Fried B, et al. The American College of Rheumatology preliminary core set of disease activity measures for rheumatoid arthritis clinical trials. The Committee on Outcome Measures in Rheumatoid Arthritis Clinical Trials. Arthritis Rheum 1993;36:729-40.

27. Croft P, Rigby AS, Boswell R, Schollum J, Silman A. The prevalence of chronic widespread pain in the general population. J Rheumatol 1993;20:710-3. 
28. Affleck G, Tennen H, Keefe FJ, Lefebvre JC, KashikarZuck S, Wright K, et al. Everyday life with osteoarthritis or rheumatoid arthritis: independent effects of disease and gender on daily pain, mood, and coping. Pain 1999;83:601-9.

29. Weyand CM, Schmidt D, Wagner U, Goronzy JJ. The influence of sex on the phenotype of rheumatoid arthritis. Arthritis Rheum 1998;41:817-22.
30. Björk M, Gerdle B, Thyberg I, Peolsson M. Multivariate relationships between pain intensity and other aspects of health in rheumatoid arthritis--cross sectional and five year longitudinal analyses (the Swedish TIRA project). Disabil Rehabil 2008;30:1429-38. doi: $10.1080 / 09638280701623356$. 